\begin{tabular}{ccc}
\hline International Journal of Engineering \& Technology, $7(4.37)(2018)$ 114-120 \\
SPC \\
Website $: \frac{w w \text {.sciencepubco.com/Index.Php/IJET }}{\text { Research Paper }}$ \\
\hline
\end{tabular}

\title{
Assessment of the Performance for a Hybrid PV / Solar Chimney
}

\author{
Abdullah Sabah Hussein ${ }^{1 *}$, Omer Khalil Ahmed ${ }^{2}$ \\ ${ }^{1,}{ }^{2}$ Technical College / Kirkuk, Northern Technical University, Iraq \\ *Corresponding author E-mail: omerkalil@yahoo.com
}

\begin{abstract}
In this study, we assessed the performance of a new design of the solar chimney by merging the collector through integrated solar panel by using a solar cell as a glass roof. Assessment of the performance of this new design is the main purpose of this study. Experimental work conducted at Kirkuk (35.46 oN, $44.39 \mathrm{oE})$ northern Iraq. The experiments conducted during the summer season. A hybrid solar chimney consisting of a solar panel cover replaces the glass cover in the conventional solar chimney. Different instruments used to measure temperature, air velocity, electric current and voltage of solar panel. An experimental model was built to anticipate the performance of a hybrid chimney.

It has been shown, that there is an increase in the temperature of the PV panel from the beginning of the day with increased of the incident solar radiation values. It is observed that the angle (45) is the best angle for the energy production. Also, it is noted that (45-panel angle) gives the highest efficiency to this system of the three angles that have been measured $\left(30^{\circ}, 35^{\circ}, 45^{\circ}\right)$. The results showed the efficiency of the PV/ solar chimney ranges from $8 \%$ to $13 \%$. The maximum rise of the air temperature in the solar collector it is found to be $2-3$ oC on a typical day.
\end{abstract}

Keywords: Assessment, Chimney, Hybrid, Performance, PV, Renewable energy.

\section{Introduction}

Renewable energy is generally defined as energy that comes from resources which are naturally replenished without a negative side on the environment (Papageorgiou 2016). Recently the approach towards searching for alternative energy has increased because the existing energy sources are depleting and will not be sufficient to meet the requirements(Mohammed, Khalil et al 2018). Electricity can be generated from solar energy through two methods; solar panels and solar power plants, which include the solar tower.

The performance of the solar panel is affected by the rise of the cell temperature, especially in hot regions. The rise in the temperature of the solar cell led to a reduction in their electrical efficiency(Ahmed and Bawa 2018). A solar chimney is one of a renewable power system that can be utilized to produce electric power as shown in Fig. (1). the air inside the solar chimney is less dense than the outside air because of the greenhouse phenomena. The warm air flows through the chimney, which fixed in the center of the system and there is flow upwards due to the buoyancy effect. This flowing air rotates the wind a turbine was installed at the base of the tower. The recent improvements to the system have included the exploration of new designs to increase the solar chimney performance and

ability to reduce the cost of this type of renewable energy system(Ahmed 2018).

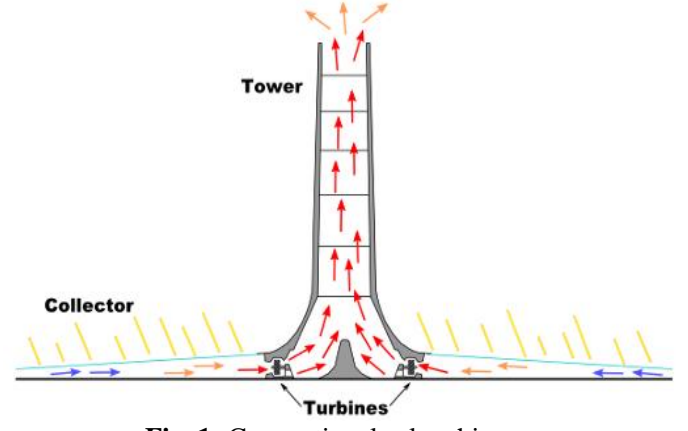

Fig. 1: Conventional solar chimney

(Ahmed and Hussein 2018) presented two new designs of the solar chimney; which integrates solar cell technology with solar chimneys. In fig. (2), the transparent cover in the conventional solar tower is replaced by solar panels. Solar cells play two roles: generate electricity and act as an absorber plate, where the air is heated by the energy radiated from the rear surface for the solar panel and warm air that flows under the solar panel working to cool the solar panel, which means increasing the efficiency of the solar panel. In addition, the kinetic energy of moving air can be utilized to produce the electricity using the wind turbine. 


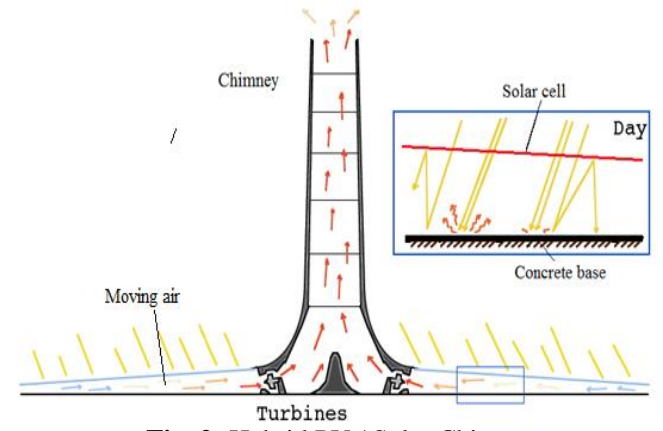

Fig. 2: Hybrid PV / Solar Chimney

(Eryener Etal 2018) presented an experimental assessment of hybrid transpired solar collector tower. This novel solar system has produced solar power efficiencies in the 16-18\% range compared to the conventional solar chimney. Also, etal 2017) studied the thermal performance of transpired solar collector updraft tower. The results indicated that transpired solar chimney efficiency ranges from $60 \%$ to $80 \%$, three times higher compared to the $25 \%$ efficiency measured with the classical solar chimney. (Boutina et al. 2017) achieved numerical study of the turbulent free convection for cooling of the solar panel in a new design of hybrid PV/T solar collector by hybridizing of a solar tower. The increase in the height of the solar chimney leads to an increase in flow velocity, which causes an increase in the kinetic energy and enhancement of heat transfer on the solar cells. (Zou et al. 2017)offered a numerical investigation of the solar enhanced passive air system. Numerical results of this system show that the novel design can keep solar cell temperature under 75 oC. (Yelpale, Wagh, and Shinde 2014) carried out an experimental analysis of the solar chimney which integrated the solar panels to increase the efficiency of the solar panel by increasing the chimney height. It is noticed that the air velocity in the passage below the solar cell increases with increasing chimney height. Results showed an increase in efficiency from 0.69 to $1.61 \%$. One of the main problems facing solar chimney technology is its low efficiency. Researchers are therefore trying to improve their performance. By making modifications to the design of the chimney and adding new parts to increase the efficiency of these chimneys (Al-kayiem and Chikere 2016). In this study, we assessed the performance of a new design of the solar chimney by merging the collector through integrated solar panel by using a solar cell as a glass roof. Assessment of the performance of this new design is the main goal of this article.

\section{Materials and Methods}

This study was conducted at Kirkuk (35.46 oN, $44.39 \mathrm{oE}$ ) in northern Iraq, considering the climate of this city ideal due to the abundance of sunshine around the days of the year. The experiments were conducted during the summer season at the roof of a building at a height of 12 meters from the ground level. The experiments were taken readings from 9 am to $4 \mathrm{pm}$ at each hour. A hybrid solar chimney consisting of a solar panel cover replace the glass cover in the classical solar chimney as shown in Fig. (3). The base of the experimental set-up was made from the wood and a chimney made of corrosion-resistant stainless steel and covered with insulating glass wool where the air inside the solar chimney is heated by the heat generated by the solar panel to made circulation of air current which moving toward the exit of the chimney.

The experimental set-up consists of the following parts (Fig. (3)): the solar cell, air duct, chimney, measurement devices, and iron structure. The solar panel absorbed the incident solar radiation. It has been fitted inside an exterior iron frame. The characteristics of the solar cell modules used are shown in Table 1. The solar panel covered the upper side of the metal-air duct entirely insulated from both sides and back. A rectangular duct is fixed vertically to the end of the lower duct to work as a chimney with dimensions $(2 \mathrm{~m}$ long and $0.67 \mathrm{~m}$ wide), the chimney is fully insulated with thermally insulated wool which has a thermal conductivity of 0.45
W/m.K)(Ahmed and Mohammed 2017c). The width and the depth of the cross-section area of the duct are $(67 \mathrm{~cm} * 10 \mathrm{~cm})$. The optimum distance between the solar panel and the base of the duct about $10 \mathrm{~cm}$ (dos, Voß, and Weinrebe 2003). A movable metal structure was fabricated for the design to estimate the effect of the tilted angle on the efficiency of the PV/solar chimney.

To evaluate and analyze the effect of different variables on the performance of the current design, the experimental set-up was fabricated for this purpose. Different instruments were used to measure temperature, air velocity, electric current and voltage of solar panel. 10 thermocouples were used on the hybrid system in different locations as shown in Fig.4. Five thermocouples were fixed along air duct of the design, two thermocouples fixed on the PV panel of the design, and two others on the base of the duct; also two sensors were fixed on the back of insulation for the design; the purpose was to find the thermal power. Four locations were used to measure the air velocity along the air duct as shown Fig.3. The velocity of the moving air was measured by a hot wire anemometer type ( MY-300) through four holes in the system to measure the kinetic energy of the flowing air. For electric current and voltage measurements from the hybrid solar chimney, two multi-meters type (SM-20) used. Small light bulbs were used to represent the load on the solar cell as shown in Fig. (5). Solar radiation was measured by the solar power meter [Solar meter SM206] which was fixed at the same location as the system
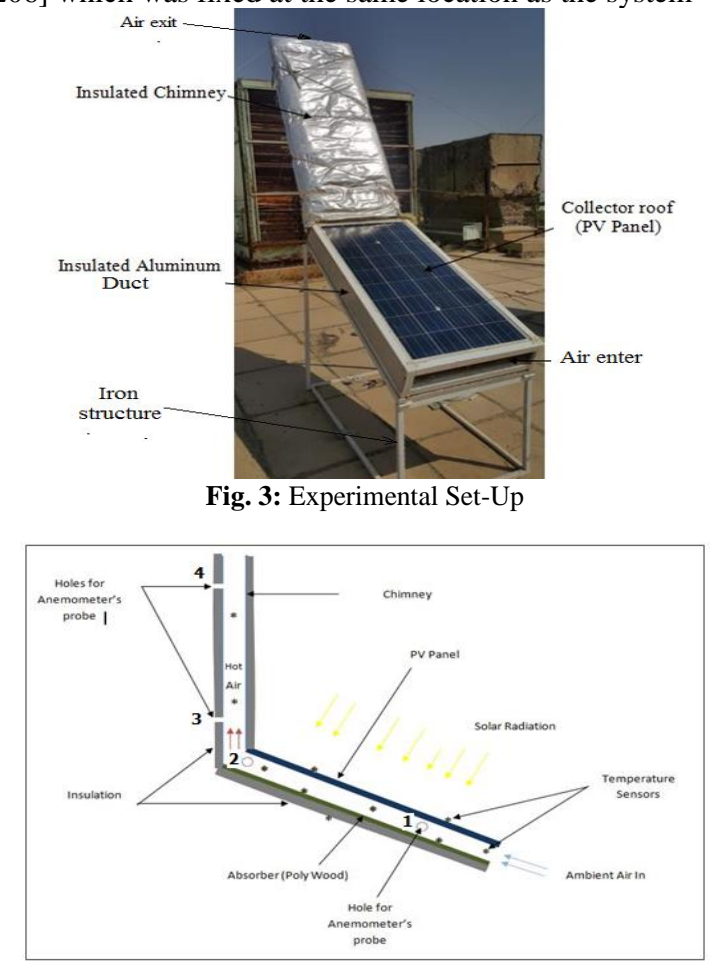

Fig. 4: Description sketch of the hybrid system

Table 1: Solar cell specification

\begin{tabular}{|l|l|}
\multicolumn{2}{|c|}{ Table 1: Solar cell specification } \\
\hline Maximum power (Pmax) & $150 \mathrm{~W}$ \\
\hline Maximum voltage (Vmax) & $17.9 \mathrm{~V}$ \\
\hline Maximum current (Imax) & $8.38 \mathrm{~A}$ \\
\hline Open voltage (Voc) & $21.9 \mathrm{~V}$ \\
\hline Short circuit current & $9.01 \mathrm{~A}$ \\
\hline Optimum operating temperature & $25 \mathrm{oC}$ \\
\hline Module size & $(1480 \times 670 \times 35) \mathrm{mm}$ \\
\hline Cell type & Polycrystalline silicon \\
\hline
\end{tabular}

Determining the error rate is one of the important issues that determine the suitability of a new design to generate electricity. Table (2) represented the uncertainty of the instruments which utilized in the study, then the uncertainty of the obtained results is evaluated by the following equation(Holman 1994): 


$$
\omega_{R}=\sqrt{\left(\frac{\partial \varphi}{\partial x_{1}} \times \psi_{1}\right)^{2}+\left(\frac{\partial \varphi}{\partial x_{2}} \times \psi_{2}\right)^{2}+\ldots \ldots . .\left(\frac{\partial \varphi}{\partial x_{n}} \times \psi_{n}\right)^{2}}
$$

Table 2: Specifications of the instruments

\begin{tabular}{|l|l|l|}
\hline Equipment & Measurement & Error \\
\hline Multi-meter & DC Current & $\pm(0.8 \%)$ \\
\hline Multi-meter & DC Voltage & $\pm(0.5 \%)$ \\
\hline Digital Thermometer & Temperature & $\pm(1 \circ \mathrm{C})$ \\
\hline Hotwire Anemometer & Wind Velocity & $\pm(3 \%)$ \\
\hline
\end{tabular}

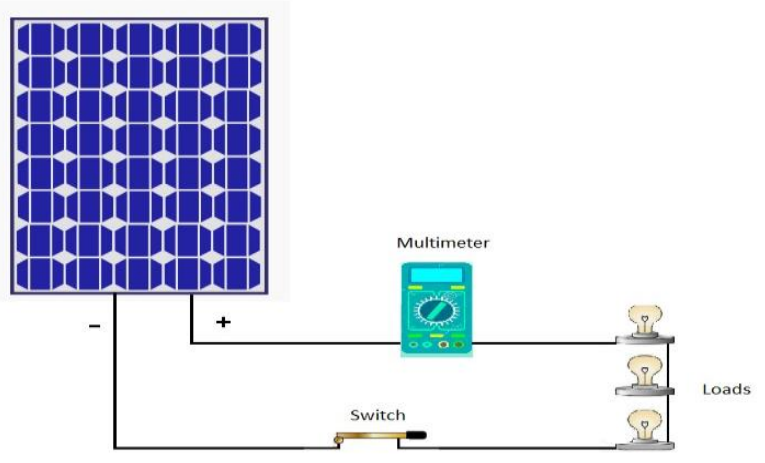

Fig. 5: Solar cell with instruments

Theoretical analysis:A hybrid PV/solar chimney has a principle work concept as shown in Fig. 5; The external air which enters from the open circumference of the duct which covered from the top by a solar cell, The air inside the duct has been heated as a result of contact with the inner surface of the solar cell and flows toward the centered position chimney to produce electricity by using the moving air to turn the wind turbines. The PV cell roof of the chimney works as an absorber. The ground under the roof heats up by radiation and transfers its heat to the airflow above it Because of the indirect heat transfer method of the system and losses, the expected efficiency of this system is as low as $15 \%$ to $30 \%$. On the other side, the design included combining the PV panel and solar chimney in one system used for electrical generating and wind energy at the same time. Thus, the hybrid $\mathrm{PV} /$ chimney collector aims to use the same location for two goals. Also, the principal purpose is to increase the electrical production of solar cells by lowering the temperature of the solar cell by cooling it. The beneficial thermal energy acquired by the air inside the duct depends on the cell temperature, the mass flow rate of the air passing through the duct, and the dimensions of the duct.

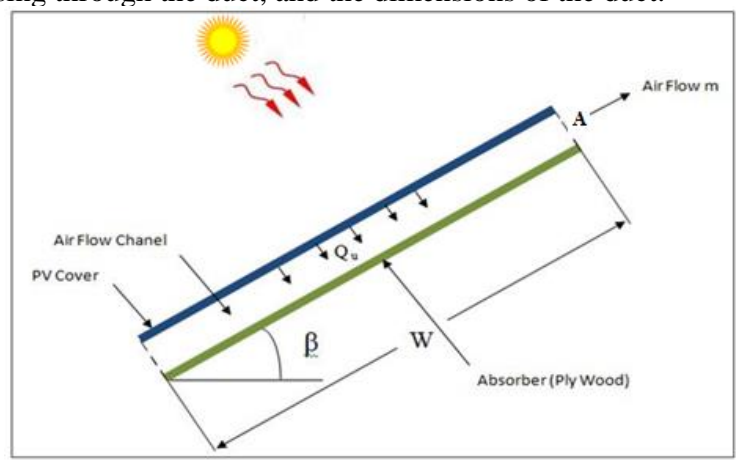

Fig. 5: Mechanism of air movement inside the PV/solar chimney

Thermal power was calculated by the following equation:

$\mathrm{Q}_{\mathrm{u}_{\mathrm{B}}}=\frac{\mathrm{m}_{\mathrm{th}} \mathrm{cp}_{\mathrm{f}}\left(\mathrm{T}_{\mathrm{fair}}-\mathrm{T}_{\mathrm{z}}\right)}{\mathrm{\gamma}_{\mathrm{L}} \mathrm{L}_{2}}$ $\gamma$ constant value equal to 0.75 (Kongduang 1997).

L1 the width of the duct.

L2 the length of the duct as shown in Fig. (6).

Ta ambient air temperature.

Tfair mean air temperature inside the duct and calculated by the following relation(K. S. Ong and Chow 2003):

$\mathrm{T}_{\text {fair }}=\gamma \mathrm{T}_{\mathrm{O}_{\text {air }}}+(1-\gamma) \mathrm{T}_{\mathrm{a}}$

$\mathrm{cp}_{\mathrm{f}}$ the specific heat capacity of the air and calculated by the following equation (K S Ong and Chow 2003):

$\mathrm{cp}_{\mathrm{f}}=\left[1.007+0.00004\left(\mathrm{~T}_{\mathrm{air}}-300\right)\right] * 10^{\mathrm{a}}$

$\mathrm{m}_{\text {th }}$ the theoretical mass flow rate and evaluated by the relation (Kasaeian et al. 2017):

$\stackrel{\mathrm{m}}{\mathrm{th}}_{\mathrm{th}}=\rho_{0} \mathrm{~V}_{\mathrm{oth}} \mathrm{A}_{0}$

$V_{\mathrm{oth}_{\mathrm{B}}}$ the velocity of the outlet air from the duct which enters the vertical chimney at point $\mathrm{A}$ in Fig. (5) and calculated from the following equation(Zhou et al. 2007):

$V_{\text {oth }}=\sqrt{2 \mathrm{~g} \mathrm{H}_{\mathrm{ch}}\left(\mathrm{T}_{\mathrm{ouir}_{\mathrm{ir}}}-\mathrm{T}_{\mathrm{a}}\right) / \mathrm{T}_{\mathrm{a}}}$

$\mathrm{P}_{0}$ Air density at the exit of the duct (point A) and could be approximated by(K. S. Ong and Chow 2003):

$P_{0}=1.1614-0.00353\left(\mathrm{~T}_{\mathrm{o}_{\text {iir }}}-300\right)$

$\mathrm{A}_{0}$ Area of the duct at point $\mathrm{A}$ and equal to $(\mathrm{L} 1 * \mathrm{~L} 2)$.

$\mathrm{T}_{\mathrm{O}_{\text {2ir }}}$ Temperature of the moving air at the exit of the duct (point A).

$\mathrm{H}_{\mathrm{ch}}$ Height of the chimney.

The experimental thermal power could be calculated by the following relation(Ahmed and Mohammed 2017a):

$\mathrm{Q}_{\mathrm{u}}=\mathrm{m}_{\mathrm{0}} \mathrm{cP}\left(\mathrm{T}_{\mathrm{o}_{\text {zir }}}-\mathrm{T}_{\mathrm{a}}\right)$

Where $\mathrm{T}_{\mathrm{O}_{\text {2ir }}}$ temperature of outlet air which calculated by the sensor at the exit of the chimney.

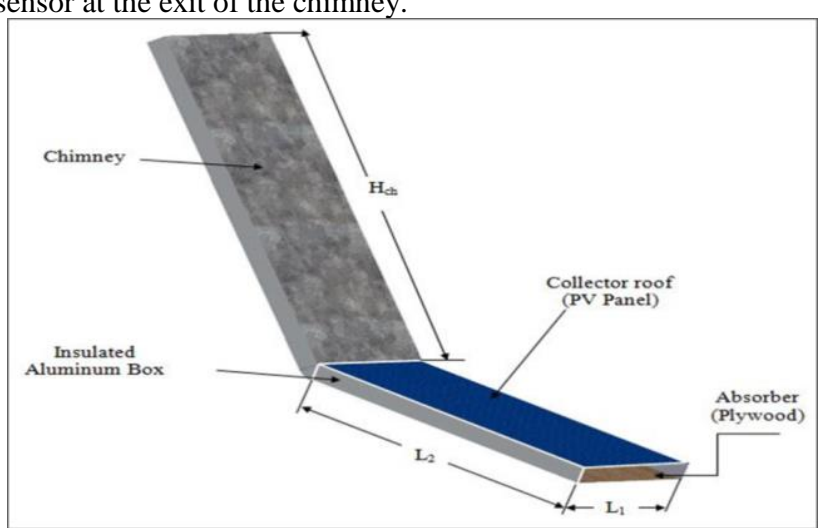

Fig. 6: Three-dimension sketch of the experimental set-up

$\mathrm{m}_{0}$ is the experimental mass flow rate which can be calculated from the following relation:

$\stackrel{\mathrm{m}}{=}=p_{0} \mathrm{~V}_{\exp } \mathrm{A}_{0}$

$V_{\exp }$ is the experimental air velocity which calculated by hot wire anemometer.

The kinetic power produced by the solar chimney depends on the mass flow rate of the air following inside the tower and calculated theoretically from the following equation(Eryener et al. 2017):

Where: 
$\mathrm{R}_{\mathrm{kthe}}=\frac{1}{2} \dot{\mathrm{m}}_{\mathrm{th}} \mathrm{V}_{\mathrm{o}_{\text {th }}}^{2}$

Also, it can be calculated experimentally by the following relation:

$\mathrm{P}_{\mathrm{k}_{\mathrm{exp}}}=\frac{1}{2} \dot{\mathrm{m}}_{\mathrm{exp}} \mathrm{V}_{\mathrm{exp}}^{2}$

The theoretical electrical power can be approximated by the following relation(Ahmed and Mohammed 2017a):

$\mathrm{P}_{\text {elthe }}=\eta_{p w} \mathrm{I}_{\mathrm{t}}$

Where:

It the total solar radiation was incident the solar cell.

$\eta_{p v}$ the efficiency of the PV panel which is a function of the cell temperature, and calculated as(Dubey, Sarvaiya, and Seshadri 2013):

$\eta_{p v}=\eta_{\mathrm{ref}}\left[1-\beta_{\mathrm{ref}}\left(\mathrm{T}_{\mathrm{pw}}-\mathrm{T}_{\mathrm{ref}}\right)\right]$

Where: $T_{p_{m}}$ The average temperature of the solar panel surface and can be obtained by fixed two sensors the surface of the solar panel.

( $\eta_{\text {ref }}, \beta_{\text {ref }}, T_{\text {ref }}$ ) are the ideal solar panel specifications and can be approximated as $(0.15,0.0041 / \mathrm{K}$, and $298 \mathrm{~K})$ (Dubey et al 2013).

To calculate the electrical power produced in practice, it is calculated by(Ahmed and Mohammed 2017b):

$P_{\text {el exp }}=V . I$

Where V and I represented the voltage and the current was measured by the multimeter.

The total power can be calculated by summation of the different types of the power as:

$P_{\text {total }}=P_{\text {ele }}+P_{k}+Q_{u_{B}}$

The thermal efficiency of the system can be estimated by(Zhou and $\mathrm{Xu} 2016$ ):

$\eta_{t h}=\frac{Q_{u b}}{A_{p v} I_{t}}$

Where, Apv area of the solar panel,

The combined electric efficiency of the PV/ solar chimney system can be expressed as follows(Ahmed and Hussein 2018):

$\eta_{\text {ele }}=\frac{P_{s c}+P_{\mathrm{sle}}}{I_{t} A_{p v}}$

Where:

$P_{g c}$ : The generated electrical energy by the wind turbine and can be expressed from the relation(Cengel and Boles 2015):

$\mathrm{P}_{\mathrm{sc}}=\mathrm{P}_{\mathrm{k}} \eta_{\mathrm{tur}}$

Where: $\eta_{\text {tur }}$ the efficiency of the wind turbine and its value ranging between ( $50-90 \%$ )(Zhou et al. 2007).

The main concept of this study is the assessment of the performance of a hybrid PV / solar chimney to reach an optimum design. The experiments have done in Kirkuk city in the north of Iraq with the GPS coordinates of $\left(35^{\circ} 28^{\prime} \mathrm{N}, 44^{\circ} 24^{\prime} \mathrm{E}\right)$. The Novel solar chimney was faced south direction with the different inclined angles to have the maximum solar radiation. At the starting of each experiment, the surface of the solar cell cleaned thoroughly.
Measurements of various variables recorded at each hour. The hourly system performance variables analyzed systematically for all test conditions. These included the solar cell temperature, outlet air temperature, air velocity along the chimney, and total generated power.

Temperature of the Solar panel:Fig. (7) explains the behavior of PV temperature for this new design, when the system at 450 inclined angle with the horizontal line. It has been showed, that there is an increase in the temperature of the PV panel from the first hours of the day until it reaches the ultimate value at noon coupled with the increase of the incident solar radiation values, after that, the temperature of the PV panel begins to decline due to the reduction in the value of solar energy and the increment in heat losses in the afternoon, the temperature of the solar cell for the new design recorded its highest values at $(67 \mathrm{oC})$ at 12 noon. These results are identical to the results of the other researchers(Ahmed and Bawa 2018)(Shahsavar and Ameri 2010).

5.2 Temperature of outlet air:

Figure (8) presents the variation of air outlet temperature during a typical clear sunny day. It is obvious that the air temperature at the chimney outlet increases with time to reaches its greatest value at 2 p.m. and then starts to decrease afterward. This trend is due to the reduction in solar energy absorbed to a value slightly lower than the heat losses, which leads to insufficient useful energy being transferred to the flowing air, therefore causing a further increase in the outlet air temperature(Guo, Yunfeng Wang, et al. 2016). The maximum value of the air temperature at the outlet for that particular day was $52{ }^{\circ} \mathrm{C}$ at $1 \mathrm{p} . \mathrm{m}$. In addition, the highest difference between the outlet and inlet air temperature was $3.3^{\circ} \mathrm{C}$.

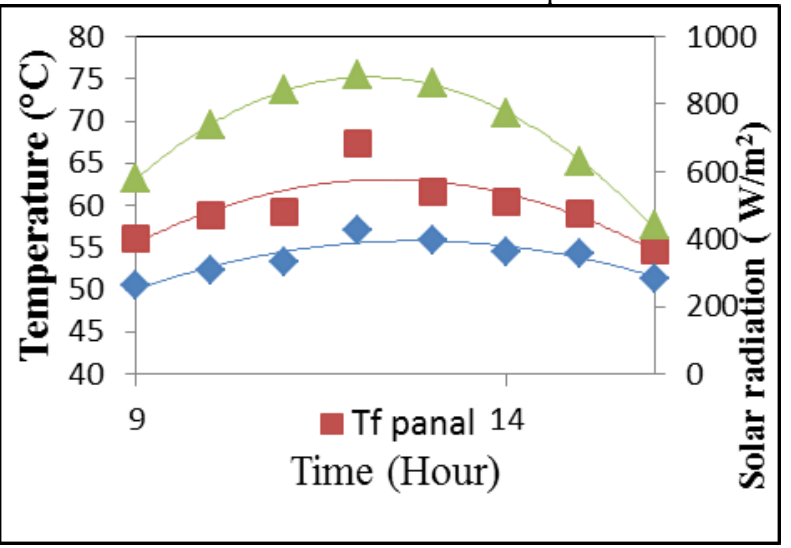

Fig. 7: Variation of PV panel temperature ( Tf panel ) and temperature of duct base ( $\mathrm{Tf} \mathrm{Ab}$ ) with the time

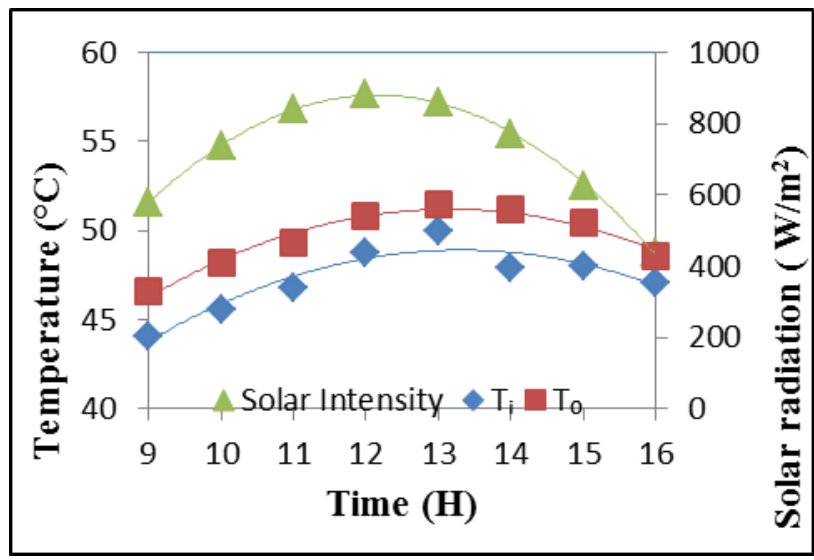

Fig. 8: Variation of the outlet and inlet air temperature with time

Air velocity:The wind velocity is the most important factor for determining the performance of conventional solar chimney. Fig. (9) shows a comparison between the air velocity for different locations along the duct of the systems. It can be seen clearly that the values of air velocities are increasing during the period between 6 a.m. and 12 noon, these velocities start to decrease after 12 noon due to the reduction of the solar radiation value and an increase in 
heat losses. The maximum value of the air velocity was $0.64 \mathrm{~m} / \mathrm{s}$ and recorded at the chimney inlet (point 2 in fig. ( 4 )), therefore the chimney inlet (intersection region between the solar panel and the solar chimney) was the best region to install the wind turbine. These results are agreeable with the results of previous articles such as(Yelpale et al. 2014)(Guo, Yuan Wang, et al. 2016).

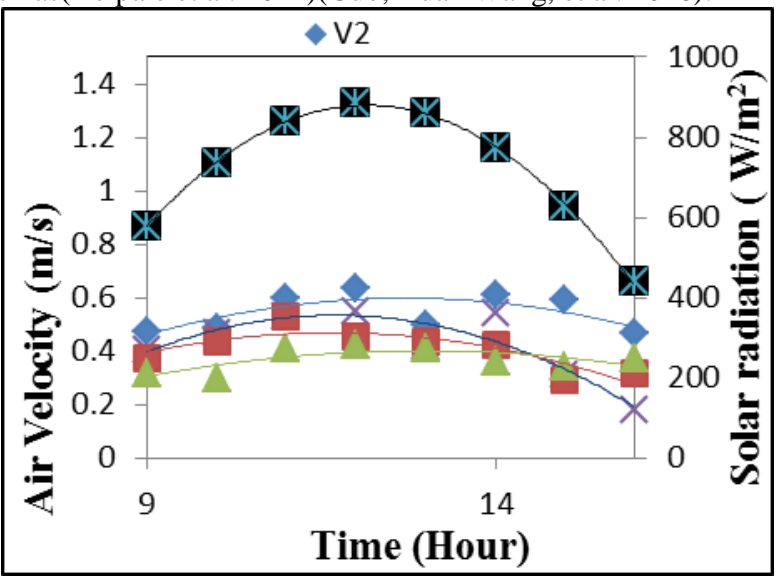

Fig. 8: Variation of the air velocity for different locations with time

Thermal power:Figure (9) shows the variation of an experimental and theoretical power during a typical day. Equation 2 and 8 used to calculate the theoretical and experimental thermal power, respectively. Similar close trends observed for the variation of useful transferred energy and the solar intensity variation with the maximum value of $968 \mathrm{~W} / \mathrm{m} 2$ at $12 \mathrm{AM}$ during this day. The novel chimney has a higher thermal power which reaches $(78 \mathrm{~W})$ at 12 noon. In addition, it noticed that thermal power increases until it reaches the maximum value at midday and begins to decrease after that due to increasing heat losses with the time of day. The maximum value depends on the solar radiation and the weather conditions. The experimental results collected from this test show a good agreement with the numerical data during the period.

Kinetic power:Figure (10) shows the variation of the experimental and theoretical kinetic power during the day. The heat transfers from the solar cell in the form of convection and radiation to the air under it. The cold air enters the duct and is heated by the hot roof (Solar cell). It is observed from Fig. 10, that the experimental value of kinetic power the end of the duct (point 2 in Fig. 4) reaches the maximum value (which was $8.52 \mathrm{~W}$ ) and tapers off after 2 p.m. for this day. This behavior is due to increasing heat losses with the time of day, accompanied by decreasing net energy absorbed in the afternoon hours. In addition, this figure shows good agreement between the experimental and numerical results.

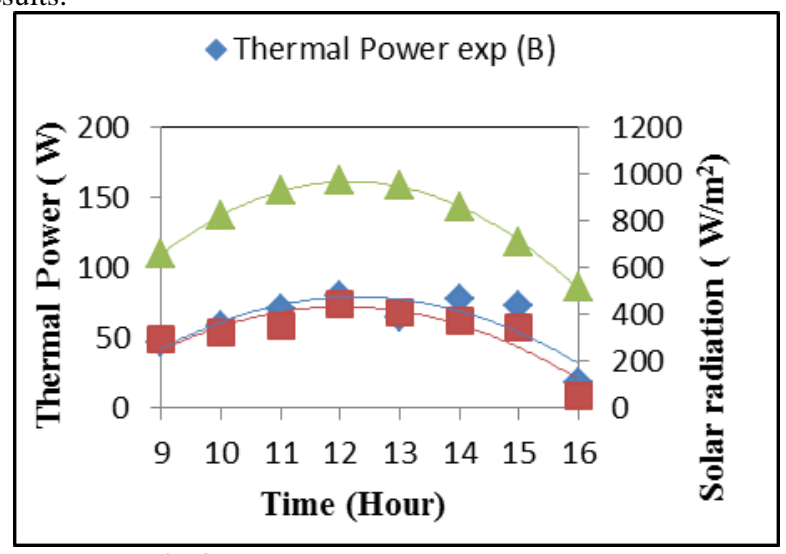

Fig. 9: Variation of thermal power with time

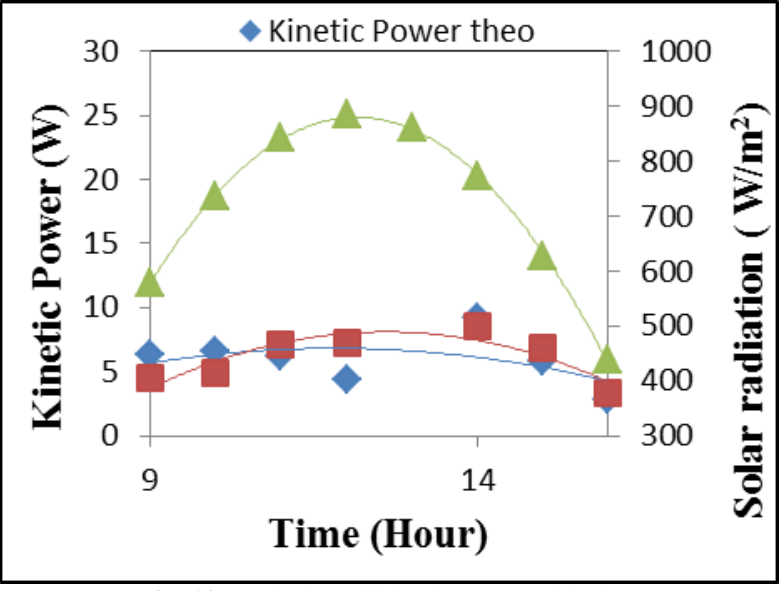

Fig. 10: Variation of kinetic power with time

Electrical power: Figure (11) shows the variation of the experimental and theoretical electrical power during a typical day. It is clear from this figure that the system can produce the electrical power up to $105 \mathrm{~W}$. The agreement between numerical predictions and experimental result is good in the afternoon period. It shows that the electrical power is a function of solar radiation. This agrees with experimental results of (Othman et al. 2016)(Popovici et al. 2016). Conventional Solar chimneys depend on the velocity of the air passing through the chimney to generate electricity, in this new design, electrical energy generated by the solar cell can be used auxiliary source for electrical power. Therefore, the beneficial energy in this new design consists of wind energy and energy produced from solar cells.

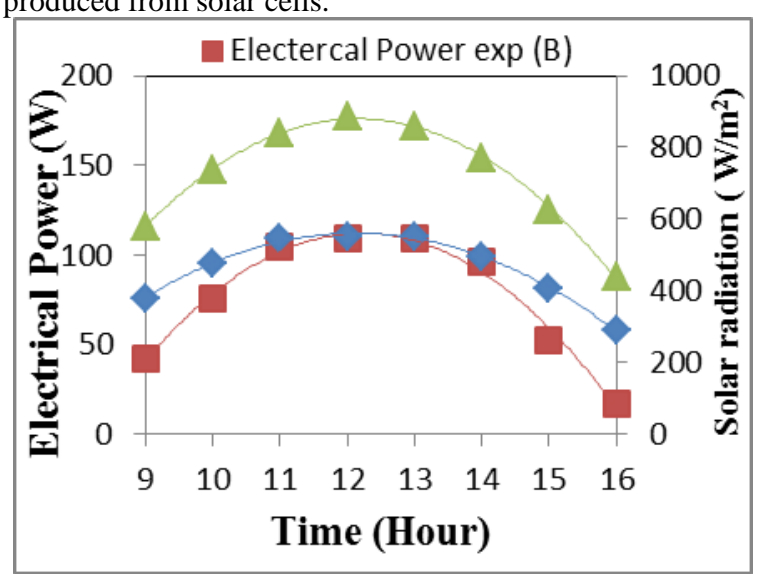

Fig. 11: Variation of electrical power with time

Efficiency of the system: Fig. (12) shows the electrical efficiency followed the solar radiation except near noon because of the increase in the solar panel temperature which causes a reduction in the electrical efficiency. The maximum value of a typical day was $11.66 \%$ at 11 a.m. and then decreased after 2 p.m. as shown in Fig.12. This agreed with the experimental results of reference(Ahmed and Mohammed 2017c). Fig. (13) shows the change of the thermal efficiency during a typical s day. A limited increase observed in the thermal efficiency during the period between 8-11 a.m. This was due to the major increase in the absorbed heat energy, coupled with comparatively little heat losses from the system to the atmosphere. After which, increased losses cause it to dropoff. The thermal efficiency reached its ultimate value of $81 \%$ at 3 p.m. and then decreased. This is due to the net energy absorbed is just less than the heat losses. Table 3 shows the amount of power that is produced during the day and observed that the major part of the power produced from solar cells if a real model is built, the power from the solar will play an important role in generating power. 


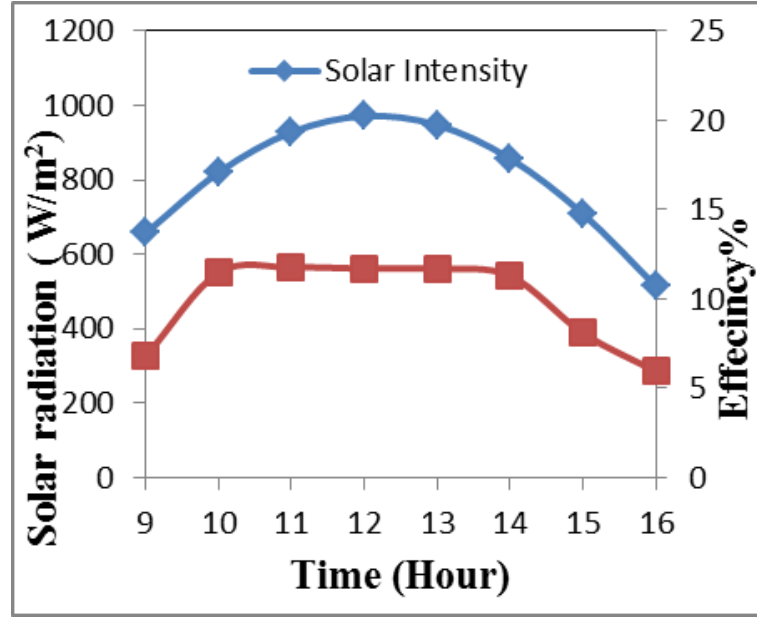

Fig. 12: Variation of electrical efficiency with time

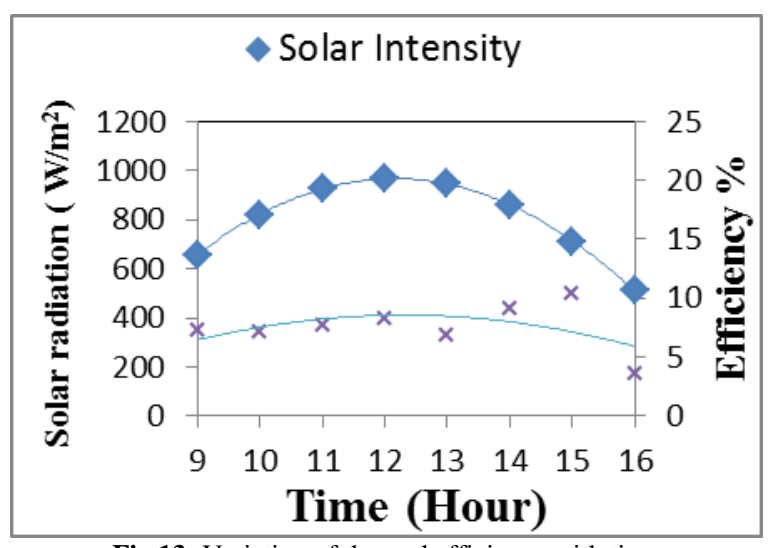

Fig.13: Variation of thermal efficiency with time

Effect of the solar cell angles: In order to study the effect of the solar cell tilt angle on the performance of the hybrid system, three angles were selected: $30 \mathrm{o}, 35 \mathrm{o}$ and $45 \mathrm{o}$. Fig. (14) shows the effect of the system angles on the total produced energy. It is observed that the angle (45o) is the best angle for the energy production. Also, it is noted that (45-panel angle) gives the highest efficiency to this system as shown in the figure (15).

Table 3: Various energies which produced by this new system.

\begin{tabular}{|c|c|c|c|}
\hline Hour & $\begin{array}{c}\text { Thermal Power } \\
(\mathrm{W})\end{array}$ & $\begin{array}{c}\text { Electrical Power } \\
(\mathrm{W})\end{array}$ & $\begin{array}{c}\text { Kinetic power } \\
(\mathrm{W})\end{array}$ \\
\hline 9 & 46.99 & 44.08 & 2.834 \\
\hline 10 & 58.37 & 93.1 & 3.98 \\
\hline 11 & 70.18 & 108 & 5.257 \\
\hline 12 & 79.43 & 112.5 & 5.296 \\
\hline 13 & 64.23 & 109.5 & 3.743 \\
\hline 14 & 77.5 & 95.81 & 5.916 \\
\hline 15 & 72.72 & 56.73 & 5.668 \\
\hline 16 & 18.2 & 30.26 & 2.22 \\
\hline $\begin{array}{c}\text { Daily aver- } \\
\text { age }\end{array}$ & 60.95 & 81.25 & 4.364 \\
\hline
\end{tabular}

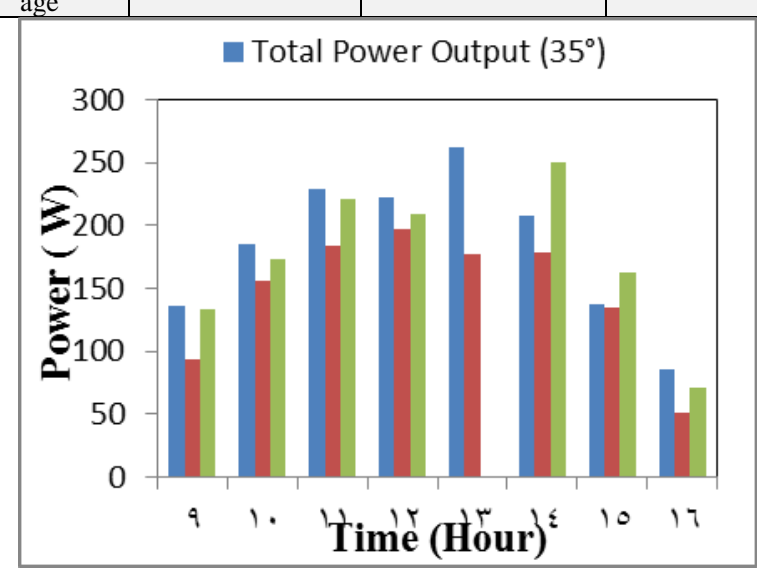

Fig. 14: Variation of produced energy with the time

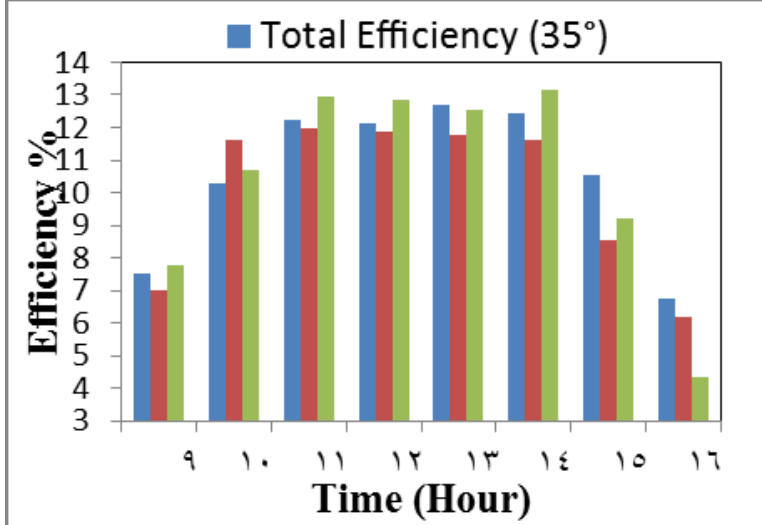

Fig. 15: Variation of the total efficiency for different angles

\section{Conclusion}

The performance of a new design of solar chimney was achieved. From the results of the analytical and experimental assessment, the following conclusions are obtained:

The temperature of the PV panel increased from the first hours of the day until it reaches the ultimate value at noon coupled with increased of the incident solar radiation values, the temperature of solar cell for the new design recorded its highest values at $(67 \mathrm{oC})$ at 12 noon. The values of air velocities are increasing during the period between 6 a.m. and noon, and then start to decrease afternoon. The maximum value of the air velocity was $0.64 \mathrm{~m} / \mathrm{s}$ and recorded at the chimney inlet, therefore, the chimney inlet was the best region to install the wind turbine. The electrical efficiency followed the solar radiation except near noon because of the increase in the solar panel temperature which causes a reduction in the electrical efficiency. It is observed that the angle (45o) of the solar cell is the best angle for the energy production and gives the highest efficiency to the system.

\section{References}

[1] Ahmed, Omer Khalil. 2018. Assessment of the Performance for a New Design of Storage Solar Collector.International Journal of Renewable Energy Research 8(1):250-57.

[2] Ahmed, Omer Khalil and Shaimaa Mohammed Bawa. 2018. "Reflective Mirrors Effect on the Performance of the Hybrid PV/Thermal Water Collector." Energy for Sustainable Development 43:235-46.

[3] Ahmed, Omer Khalil, and Abdullah Sabah Hussein. 2018. "New Design of Solar Chimney (Case Study)." Case Studies in Thermal Engineering 11(December 2017):105-12.

[4] Ahmed, Omer Khalil, and Zala Aziz Mohammed. 2017a. "Dust Effect on the Performance of the Hybrid PV/Thermal Collector." Thermal Science and Engineering Progress 3:114-22. Retrieved (http://linkinghub.elsevier.com/retrieve/pii/S2451904917301543).

[5] Ahmed, Omer Khalil, and Zala Aziz Mohammed. 2017b. "Dust Effect on the Performance of the Hybrid PV/Thermal Collector." Thermal Science and Engineering Progress 3:114-22.

[6] Ahmed, Omer Khalil, and Zala Aziz Mohammed. 2017c. "Influence of Porous Media on the Performance of Hybrid PV/Thermal Collector." Renewable Energy 112:378-87. Retrieved (http://dx.doi.org/10.1016/j. renene. 2017.05.061).

[7] Al-kayiem, Hussain H. and Ogboo Chikere. 2016. "Historic and Recent Progress in Solar Chimney Power Plant Enhancing Technologies." Renewable and Sustainable Energy Reviews 58:1269-92.

[8] Boutina, L., A. Khelifa, K. Touafek, M. Lebbi, and M. Tahar Baissi. 2017. "Improvement of PVT Air-Cooling by the Integration of a Chimney Tower ( CT / PVT )." Applied Thermal Engineering 129:1181-88.

[9] Cengel, Yunus A. and Michael A. Boles. 2015. Thermodynamics: An Engineering Approach 8th Edition.

[10] dos, M. A., A. Voß, and G. Weinrebe. 2003. "Thermal and Technical Analyses of Solar Chimneys." Solar Energy 75(6):511-24.

[11] Dubey, Swapnil, Jatin Narotam Sarvaiya, and Bharath Seshadri. 2013. "Temperature Dependent Photovoltaic ( PV ) Efficiency and Its Effect on PV Production in the World A Review." Energy Pro- 
$\begin{array}{lll}\text { cedia } 33: 311-21 . & \text { Retrieved }\end{array}$

(http://dx.doi.org/10.1016/j.egypro.2013.05.072)

[12] Eryener, Dogan, John Hollick, and Hilmi Kuscu. 2017. "Thermal Performance of a Transpired Solar Collector Updraft Tower." Energy Conversion and Management 142:286-95. Retrieved (http:// dx.doi.org /10.1016/j.enconman.2017.03.052).

[13] Eryener, Dogan and Hilmi Kuscu. 2018. "Hybrid Transpired Solar Collector Updraft Tower.” Solar Energy 159(April 2017):561-71. Retrieved (https://doi.org/10.1016/j.solener.2017.11.035).

[14] Guo, Penghua, Yuan Wang, Qinglong Meng, and Jingyin Li. 2016 "Experimental Study on an Indoor Scale Solar Chimney Setup in an Artificial Environment Simulation Laboratory." Applied Thermal Engineering 107(July):818-26.

[15] Guo, Penghua, Yunfeng Wang, Jingyin Li, and Yuan Wang. 2016. "Thermodynamic Analysis of a Solar Chimney Power Plant System with Soil Heat Storage." Applied Thermal Engineering 100(March):1076-84.

[16] Holman, J. P. 1994. Experimental Methods for Engineers.

[17] Kasaeian, A. B., Sh Molana, K. Rahmani, and D. Wen. 2017. “A Review on Solar Chimney Systems." Renewable and Sustainable Energy Reviews 67(January):954-87. Retrieved (http://dx.doi.org/10.1016/j.rser.2016.09.081).

[18] Kongduang, W. 1997. "Study of the Natural Ventilation of Habitation by Using a Metallic Solar Wall under Tropical Climate." 18.

[19] Mohammed, Fayadh, Omer Khalil, and Ahmed Emad. 2018. "Effect of Climate and Design Parameters on the Temperature Distribution of a Room." Journal of Building Engineering 17(February):115-24.

[20] Ong, K. S., and C. C. Chow. 2003. "Performance of a Solar Chimney." Solar Energy 74(1):1-17.

[21] Ong, K. S., and C. C. Chow. 2003. "Performance of a Solar Chimney." Solar Energy 74:1-17.

[22] Othman, M. Y. et al. 2016. "Performance Analysis of PV/T Combi with Water and Air Heating System: An Experimental Study." Renewable Energy 86 716-22.

[23] Papageorgiou, Christos D. 2016. "Enclosed Solar Chimney Power Plants with Thermal Storage." Open Access Library Journal OALib 03(05):1-18.

[24] Popovici, Cătălin George, Sebastian Valeriu Hudişteanu, Theodor Dorin Mateescu, and Nelu-Cristian Chereches. 2016. "Efficiency Improvement of Photovoltaic Panels by Using Air Cooled Heat Sinks." Energy Procedia 85(November 2015):425-32.

[25] Shahsavar, A. and M. Ameri. 2010. "Experimental Investigation and Modeling of a Direct-Coupled PV/T Air Collector." Solar Energy 84(11):1938-58. Retrieved (http://dx.doi.org/10.1016/j.solener.2010.07.010).

[26] Yelpale, Shankar J., Prof M. M. Wagh, and Prof N. N. Shinde. 2014. "Integration of Solar Chimney with PV Panel for Improving Performance of Polycrystalline Solar PV System.” 4(8):669-74.

[27] Zhou, Xinping and Yangyang Xu. 2016. "Solar Updraft Tower Power Generation." Solar Energy 128:95-125. Retrieved (http://dx.doi.org/10.1016/j.solener. 2014. 06.029).

[28] Zhou, Xinping, Jiakuan Yang, Bo Xiao, and Guoxiang Hou. 2007. "Simulation of a Pilot Solar Chimney Thermal Power Generating Equipment." Renewable Energy 32(10):1637-44.

[29] Zou, Zheng, Hengxiang Gong, Jingshu Wang, and Shilie Xie. 2017. Numerical Investigation of Solar Enhanced Passive Air Cooling System for Concentration Photovoltaic Module Heat Dissipation." 5(3):3-8. 